\title{
APENDISITIS AKUT SUPURATIF ET CAUSA BLASTOCYSTIS HOMINIS
}

\author{
Poppy M. Lintong \\ Eddy H. Tambajong
}

\author{
Bagian Patologi Anatomi Fakultas Kedokteran Universitas Sam Ratulangi Manado \\ Email:mplin@yahoo.com
}

\begin{abstract}
Blastocystis hominis is an anaerob protozoan parasite which lives in human and animal intestines. It is a low pathogen, common in tropical areas, and it causes an intestinal tract disease with diarrhea symptoms. Albeit, it is rarely seen in tissue sections. The clinical diagnosis is usually confirmed with a microscopic examination of the stool which can directly find the parasites by using trichrome stain. We reported a case of a 52-year-old man with abdominal pain that was suspected of having a perforated appendix, or an appendix tumor in the differential diagnosis. The appendix macroscopic feature was $7 \mathrm{~cm}$ in length and 1.5-2.5 $\mathrm{cm}$ in diameter. The cut section showed a widening of its lumen and the distal part was filled with a gelatinous mass. The microscopic slides stained with hematoxylin and eosin showed some infiltration of polymorphonuclear cells in the muscle layer of the appendix and foci of round structures in the submucosa layer, known as Blastocystis hominis. Some authors have reported from the endoscopy and biopsy examination that these parasites did not infiltrate into the intestinal mucosa. But in this case, we found their infiltration towards the mucosa and submucosa layers of the appendix.
\end{abstract}

Keywords: Blastocystis hominis, acute suppurative appendicitis

\begin{abstract}
Abstrak: Blastocystis hominis adalah parasit protozoa anaerob yang hidup dalam usus manusia maupun hewan, yang sering dijumpai di daerah tropis. Patogenisitas parasit ini rendah tetapi dapat menyebabkan gangguan saluran pencernaan dengan gejala diare. Blastocystis hominis jarang terlihat pada potongan jaringan. Untuk menunjang diagnosis klinis biasanya dilakukan pemeriksaan tinja mikroskopis yang dapat menemukan secara langsung Blastocystis hominis dengan pewarnaan trikrom. Kami melaporkan kasus seorang laki-laki berusia 52 tahun dengan gejala klinis sakit perut yang diduga sebagai apendisitis perforasi, dengan diagnosis diferensial tumor apendiks. Hasil pemeriksaan histopatologik jaringan secara makroskopik menunjukkan apendiks berukuran panjang $7 \mathrm{~cm}$ dan diameter 1,5-2,5 cm. Pada penampang melintang terlihat lumen sangat melebar, dan bagian distal berisi massa seperti gelatin. Pada sediaan mikroskopik dengan pengecatan rutin H.E. yang memperlihatkan penampang melintang apendiks, tampak lapisan muskularis dengan sebukan sel-sel radang jenis polimorfonuklear. Juga pada salah satu bagian di lapisan submukosa terlihat sejumlah struktur bulat yang menunjukkan gambaran Blastocystis hominis. Beberapa peneliti melaporkan dari hasil endoskopi dan biopsi bahwa parasit ini tidak menginvasi mukosa usus, namun pada kasus ini terlihat Blastocystis hominis telah menembus lapisan mukosa sampai submukosa apendiks.
\end{abstract}

Kata kunci: Blastocystis hominis, apendisitis akut supuratif.

Blastocystis hominis merupakan parasit protozoa anaerobik. ${ }^{1,2}$ Pada tahun 1991 Zierdt menggolongkannya sebagai sporozoa yang menyebabkan penyakit blastokistosis (Zierdt-Garavelli disease) pada manusia. ${ }^{1}$ Parasit ini pertama kali dilaporkan oleh 
Alexeieff pada tahun 1911, kemudian oleh Brumpt pada tahun 1912. ${ }^{2}$ Selain pada manusia, parasit ini juga ditemukan pada hewan seperti kera dan babi, dan mungkin marmut, reptilia, kecoa, tikus dan hewan lainnya. ${ }^{2}$ Blastocystis hominis berbentuk vakuola telah dibuktikan terdapat pada tinja tikus rumah ${ }^{3}$, tetapi pada anjing dan kucing jarang ditemukan. ${ }^{4}$

Blastocystis hominis terutama ditemukan di daerah tropis. Parasit ini banyak ditemukan pada tentara yang kembali dari medan perang dan pada orang-orang yang berpergian. ${ }^{2}$ Pada pemeriksaan rutin imigran di Timur Laut Taiwan ditemukan 188 orang dari 932 imigran $(20,2 \%)$ telah terinfeksi dengan Blastocystis hominis. Prevalensi ini dibandingkan dengan imigran dari negara-negara Asia Tenggara (Indonesia 26,4\%; Vietnam 20,6\%, Filipina $19,3 \%)$ lebih tinggi daripada Cina $(7,6 \%){ }^{5}$ Epidemiologi Blastocystis hominis di Amerika Serikat sudah dilaporkan di 48 negara bagian dan di Columbia pada tahun 2002-2004. Prevalensi infeksi setiap tahun menurun dari $23 \%$ pada tahun 2002 menjadi $11 \%$ pada tahun 2004. Infeksi lebih tinggi terjadi di bulan September dan Oktober terutama di negara-negara pesisir pantai. Infeksi pada perempuan dua kali lebih sering daripada laki-laki, dan biasanya pada usia 40-49 tahun. ${ }^{6}$ Pada studi epidemiologi yang dilakukan di Canada usia rata-rata yang terinfeksi Blastocystis hominis yaitu 37 tahun, dan pada perempuan mencapai $55 \% .^{7}$

Patogenisitas infeksi Blastocystis hominis masih diperdebatkan ${ }^{1}$ apakah parasit ini komensal atau patogen. ${ }^{2,9}$ Beberapa kepustakaan menyebutkan Blastocystis hominis merupakan protozoa yang kurang patogen dan menyebabkan penyakit pada usus bila jumlahnya besar. ${ }^{8}$ Beberapa ekspertisi memperlihatkan bahwa tidak terdapat korelasi antara adanya Blastocystis hominis dan gejala diare pada pasien yang dilaporkan meningkat terutama pada kasus dengan imunokompromais, pelancong atau wisatawan, homoseksual, dan anak-anak titipan. ${ }^{9}$ Blastocystis hominis sebagai agen protozoa berperan dan berpotensi patogen menimbulkan penyakit diare telah diteliti di Baghdad dan disimpulkan bahwa Blastocystis hominis merupakan patogen pada kasus dengan gejala simtomatik diare. ${ }^{10}$ Blastocystis hominis sebagai parasit manusia menimbulkan gangguan perut seperti anoreksia, diare, dan flatus. ${ }^{11}$

Biopsi mukosa dari kasus yang terkena infeksi Blastocystis hominis biasanya normal. Bila tidak normal, biopsi hanya memperlihatkan sebukan sel-sel radang ringan yang tidak spesifik. Parasit ini jarang menyebabkan destruksi mukosa, serta tidak memenetrasi dan menginvasi jaringan. ${ }^{1,8}$ Melalui endoskopi, mukosa usus terlihat normal. ${ }^{1}$ Blastocystis hominis dapat didiagnosis juga melalui pemeriksaan sitologi dari bahan bilasan usus. ${ }^{1}$ Infeksi Blastocystis hominis juga dihubungkan dengan kolitis ulserosa, ileitis terminal, dan enteritis yang dapat disembuhkan dengan metronidazole. ${ }^{1}$ Infeksi Blastocystis hominis sudah dilaporkan pada anak berusia empat tahun dengan gejala diare dan demam serta feses yang mengandung darah. Pada kolonoskopi terlihat ulkus superfisial dengan pseudomembran di seluruh kolon dan pada pemeriksaan tinja ditemukan Blastocystis hominis. Pada pemeriksaan histologik jaringan biopsi ditemukan sel-sel radang pada mukosa usus besar, pada ulkus di lapisan mukosa ditemukan Blastocystis hominis berbentuk bulat atau oval dengan vakuola sentral yang bergranula dan berinti satu disertai infiltrasi sel radang. ${ }^{2}$

Lebih dari $34,7 \%$ Blastocystis hominis terdapat pada individu yang secara klinis tidak menunjukkan gejala. Pasien yang simptomatik biasanya ditandai dengan gejala nyeri perut, diare cair, konstipasi, anoreksia, mual, flatulen, dan penurunan berat badan. Gejala ini bisa ditemukan selama lebih dari dua minggu. ${ }^{1,2}$ Beberapa penulis menyebutkan bahwa Blastocystis hominis termasuk salah satu penyebab diare. ${ }^{12}$ Infeksi Blastocystis hominis juga ditemukan pada pasien irritable bowel syndrom $(I B S)^{13}$ dan juga sudah dilaporkan pada inflammatory bowel disease (IBD) dan diare kronik. ${ }^{14}$ Blastocystis hominis dinyatakan juga sebagai parasit oportunis- 
tik dan ditemukan pada pasien imunosupresi dan imunokompromais. Gejala klinik berhubungan dengan beratnya infeksi dan virulensi strain Blastocystis hominis. ${ }^{2}$

Diagnosis infeksi Blastocystis hominis secara konvensional dibuat melalui pemeriksaan langsung dibawah mikroskop dari bahan hapusan feses dengan pewarnaan trikrom. Biasanya Blastocystis hominis ditemukan berbentuk vakuol dan dianggap bermakna jika ditemukan lebih dari lima parasit per $400 \mathrm{x}$ lapang pandang besar. ${ }^{2}$ Blastocystis hominis dapat juga dideteksi melalui polymerase chain reaction (PCR). ${ }^{15}$

Apendisitis akut dapat terjadi pada setiap umur, sering pada usia dewasa dan dewasa muda, serta laki-laki (7\%) lebih sering daripada perempuan. ${ }^{16}$ Pada awalnya apendisitis akut terjadi karena peningkatan tekanan intraluminal yang mengganggu aliran vena. Pada 50-80\% kasus dihubungkan dengan obstruksi lumen apendiks, dan biasanya disebabkan karena massa dari kotoran yang menyerupai batu kecil yang disebut batu tinja (fekolit). Penyebab yang lebih jarang ialah batu empedu, tumor, atau massa dari cacing (oxyuriasis vermicularis). Cedera iskemik dan stasis dari isi lumen menguntungkan bagi proliferasi bakteri, mencetuskan proses radang, edema jaringan, dan infiltrasi netrofil polimorfonuklear (PMN) dari lumen sampai dinding muskularis dan jaringan lunak periapendikuler. Pada awal apendisitis akut terjadi edema dan kongesti pada lapisan subserosa serta infiltrasi sel-sel radang netrofil pada seluruh lapisan apendiks. ${ }^{16}$

Diagnosis apendisitis akut ditegakkan bila terdapat infiltrasi netrofil menembus lapisan muskularis. Pada kasus berat eksudat radang dan netrofil dapat memberi reaksi fibrinopurulen, dan bila proses ini berlangsung terus dapat menyebabkan pembentukan abses fokal pada dinding apendiks yang disebut apendisitis akut supuratif. ${ }^{16}$

Gambaran klinik apendisitis mulamula pada awalnya ditandai oleh nyeri daerah periumbilikus, kemudian nyeri berpindah ke perut kuadran kanan bawah (titik Mc Burney). Gejala lain berupa mual, muntah atau keduanya, perut teraba tegang terutama di daerah usus buntu, demam ringan, dan leukositosis. ${ }^{16}$

\section{LAPORAN KASUS}

Seorang laki-laki berusia 52 tahun dirawat di rumah sakit dengan gejala nyeri perut. Oleh dokter bedah didiagnosis apendisitis perforasi dengan diagnosis diferensial tumor apendiks. Setelah dilakukan apendektomi, jaringan apendiks di kirim ke dokter ahli Patologi Anatomi.

Pemeriksaan makroskopik apendiks ukuran panjang $7 \mathrm{~cm}$, lebar $1,5 \times 2,5 \mathrm{~cm}$. Pada penampang irisan transversal terlihat lumen sangat melebar, dan pada bagian distal tampak berisi bahan seperti gelatin (Gambar 1 A, 1 B, dan 2).

Pemeriksaan sediaan mikroskopik dengan pengecatan rutin hematoksilin eosin menunjukkan penampang melintang apendiks. Dinding otot meregang dan menipis, lumen terisi banyak bahan lendir, terutama di bagian distal dimana lapisan mukosa umumnya hilang, sedangkan pada bagian proksimal masih tersisa sedikit. Selain itu terlihat tumpukan sel sel radang yang didominasi jenis netrofil polimorfonuklear, dan edema pada submukosa (Gambar 3 dan 4). Pada dinding submukosa bagian distal apendiks dan ke arah lumen ditemukan sejumlah struktur bulat, yang menunjukkan Blastocystis hominis (Gambar 5 dan 6). Dari gambaran makroskopik dan mikroskopik disimpulkan kasus ini sebagai apendisitis akut supuratif et causa Blastocystis hominis.

\section{BAHASAN}

Diagnosis apendisitis akut supuratif ditegakkan berdasarkan adanya infiltrasi selsel radang PMN dari lapisan mukosa sampai serosa; ${ }^{16}$ hal tersebut sesuai dengan yang ditemukan pada kasus ini (Gambar 36). Kasus ini seorang laki-laki berusia 52 tahun; hal ini sesuai kepustakaan yang menyebutkan bahwa apendisitis akut lebih sering terjadi pada laki-laki daripada perempuan, dan sering usia dewasa. ${ }^{16}$ 

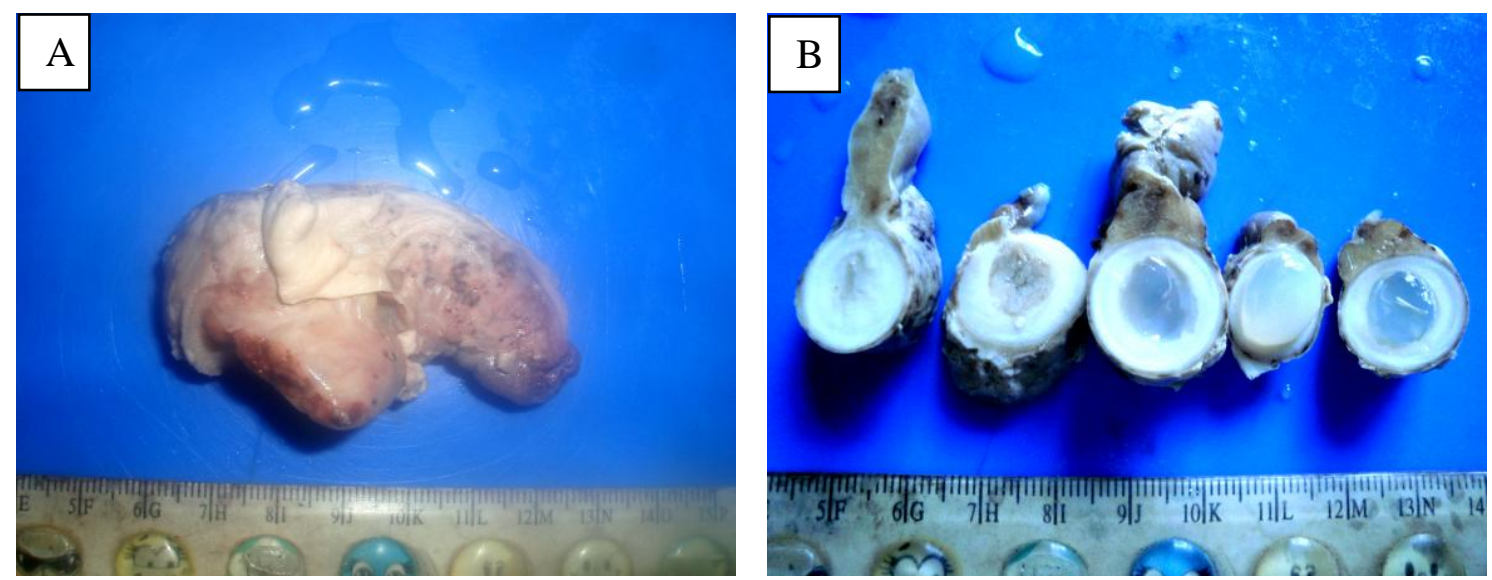

Gambar 1. A, gambaran makroskopik apendiks, ukuran panjang $7 \mathrm{~cm} . \mathrm{B}$, penampang melintang pada bagian distal apendiks yang kurang memperlihatkan lapisan mukosa, sedangkan pada bagian proksimal masih memperlihatkan lapisan mukosa dan lumen yang terisi massa seperti gelatin.

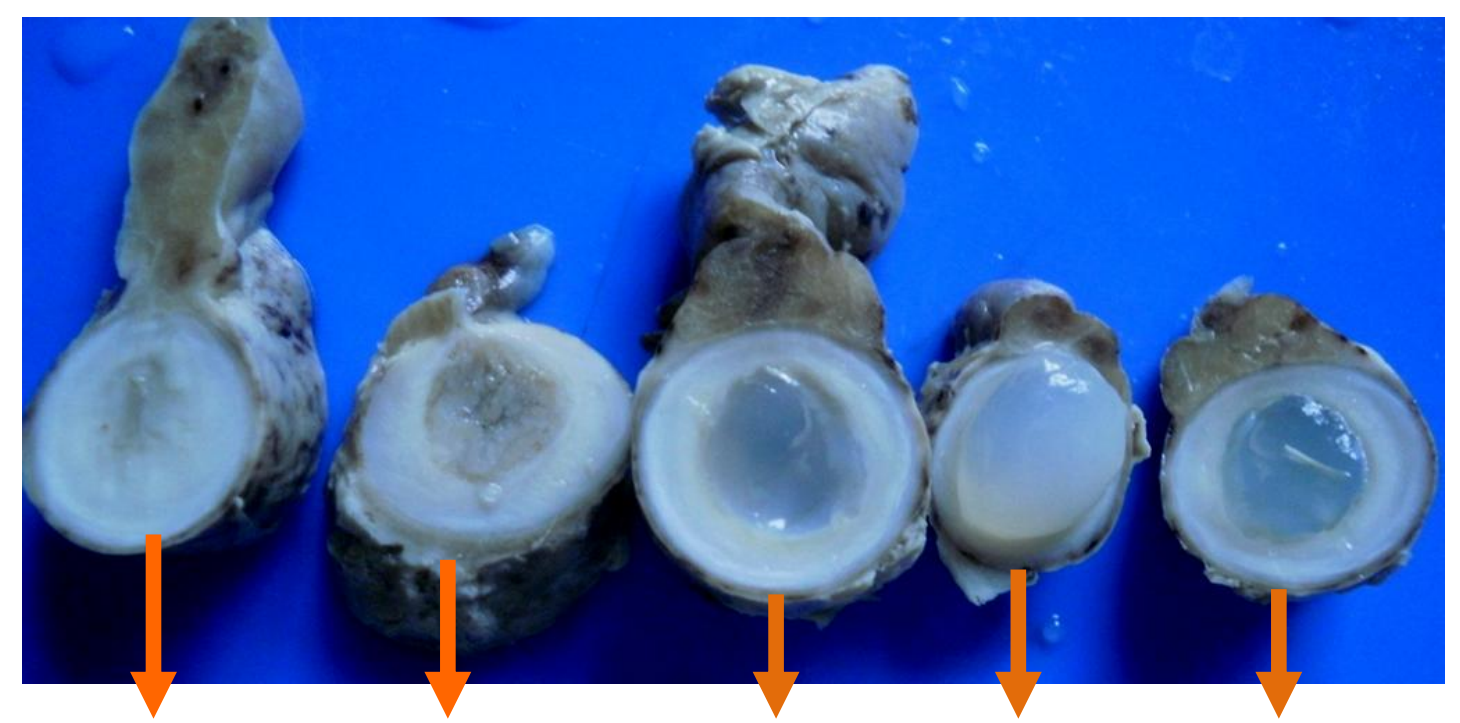

Bagian proksimal apendiks,

Bagian distal apendiks, dinding menipis, terlihat lapisan mukosa sampai serosa lapisan mukosa hilang, lumen berisi bahan gelatin

Gambar 2. Potongan melintang apendiks dari bagian proksimal sampai distal.

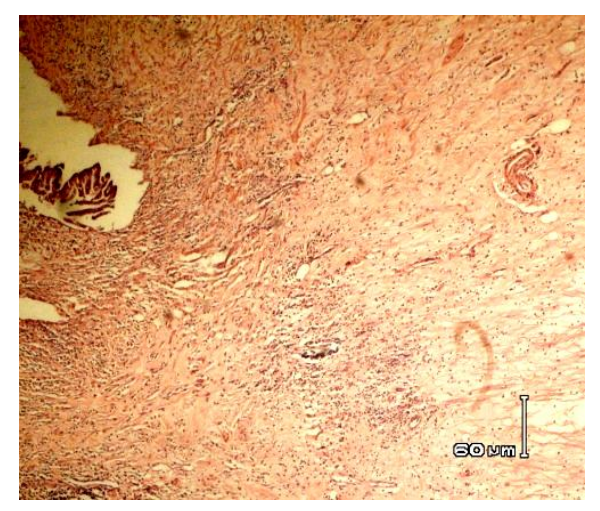

Gambar 3. Gambaran mikroskopik apendiks bagian proksimal, masih terlihat lapisan mukosa, submukosa, sampai muskularis. Tampak edema submukosa dan infiltrasi sel-sel radang sampai lapisan muskularis. 

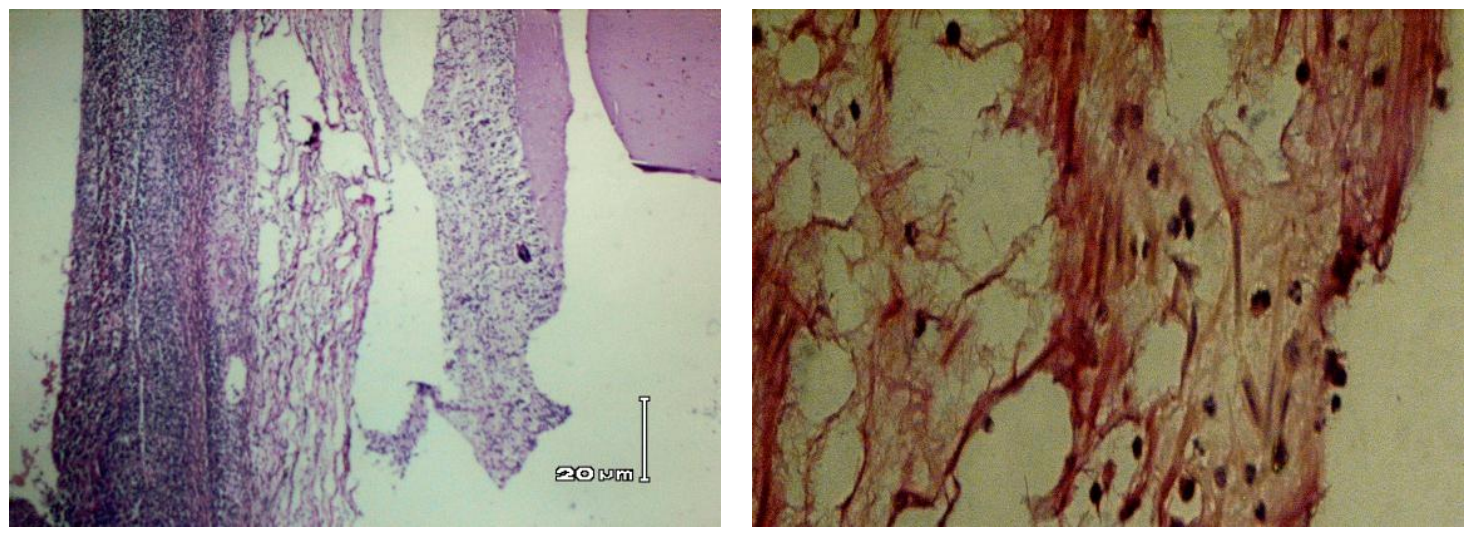

Gambar 4. Gambaran mikroskopik apendisitis akut supuratif: infiltrasi sel-sel radang netrofil PMN dari lumen sampai ke lapisan serosa (sebelah kiri pembesaran $40 \mathrm{x}$; sebelah kanan $400 \mathrm{x}$ ).
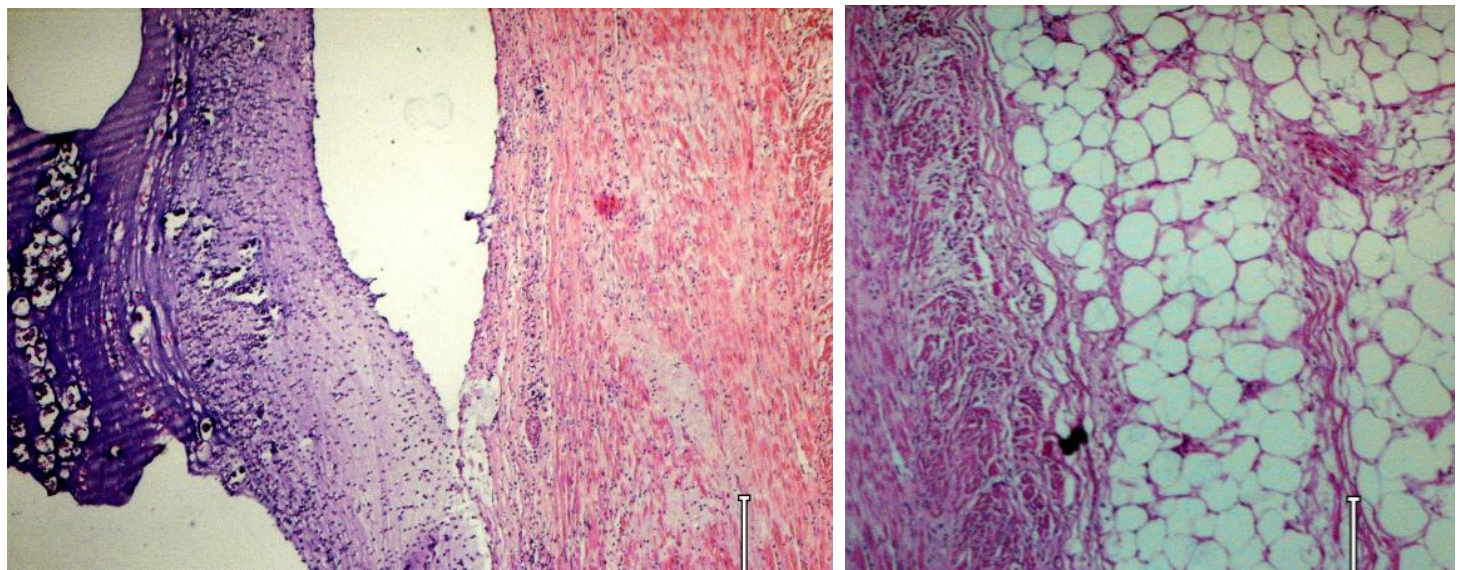

Gambar 5. Gambaran mikroskopik apendiks bagian distal, lapisan mukosa digantikan bahan lendir dengan banyak Blastocystis hominis
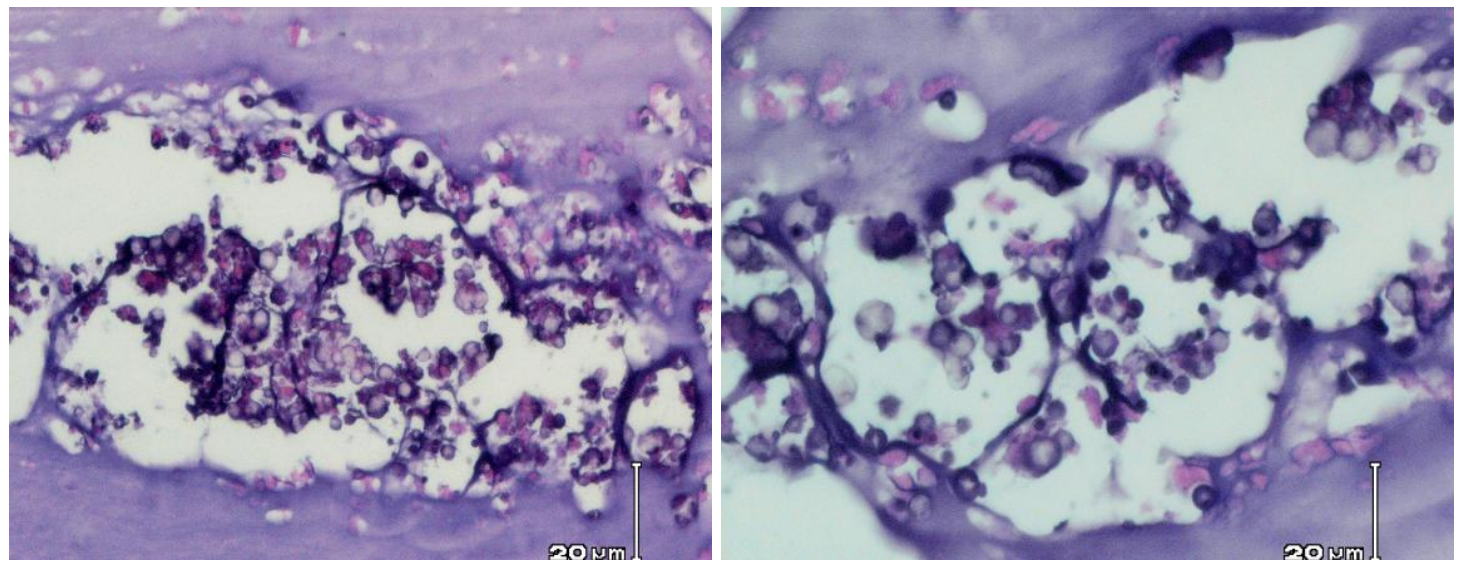

Gambar 6. Gambaran mikroskopik Blastocystis hominis umumnya berbentuk vakuol yang mengisi 50-95\% sel dan tersusun konsentris terhadap membran luar, inti dan sitoplasma terdesak ke tepi sehingga sel tampak kosong. 
Penyebab utama terjadinya apendisitis akut ialah obstruksi (50-80\%). Obstruksi dapat menyebabkan sekresi cairan lendir atau musin yang terus menerus dalam lumen apendiks sehingga menyebabkan tekanan intraluminal meningkat dan mengakibatkan kolaps vena. Akibatnya aliran darah ke apendiks berkurang, terjadi cedera iskemik dan hal ini menguntungkan bagi pertumbuhan bakteri. ${ }^{16}$

Pada kasus ini penyebab obstruksi yakni karena parasit Blastocystis hominis yang mengisi lumen apendiks dan menginvasi mukosa apendiks. Secara makroskopik dinding apendiks menipis (pada bagian distal) dan berisi bahan gelatin (Gambar 1 dan 2). Hal ini merupakan penyebab yang jarang dari apendisitis akut karena apendisitis jenis ini lebih sering disebabkan oleh batu tinja (fekolit). Penyebab yang lebih jarang dapat juga disebabkan karena cacing Oxyuris vermicularis, ${ }^{16}$ namun Blastocystis hominis sebagai agen penyebab belum pernah dilaporkan. Blastocystis hominis adalah parasit golongan protozoa yang secara morfologi mempunyai empat bentuk yaitu vakuola, granuler, amuboid, dan kista. ${ }^{2}$ Pada kasus ini Blastocystis hominis berbentuk vakuola, berbentuk bulat, ditengah ada struktur vakuol yang tampak transparan (Gambar 6). Vakuol disebut badan sentral yang dikelilingi sitoplasma perifer yang mengandung inti, mitokondria dan badan Golgi. ${ }^{2}$ Bentuk vakuol paling sering ditemukan di dalam tinja maupun biakan. ${ }^{2}$ Pada kasus ini badan-badan vakuol Blastocystis hominis telah menginvasi dan merusak lapisan mukosa apendiks, padahal sesuai kepustakaan disebutkan bahwa parasit jarang menyebabkan destruksi mukosa, tidak menginvasi jaringan. ${ }^{1,8}$ Pada beberapa kasus yang sudah dilaporkan infeksi Blastocystis hominis juga dihubungkan dengan ulkus di lapisan mukosa. ${ }^{2}$

Infeksi Blastocystis hominis pada penderita simtomatik umumnya memberi gejala klinik diare. ${ }^{1,2,8,12,14}$ Pada kasus ini tidak terdapat gejala diare. Nyeri perut diduga disebabkan karena vakuol-vakuol Blastocystis hominis yang mengakibatkan obstruksi lumen apendiks, bahkan menginvasi dan merusak lapisan mukosanya dan bermanifestasi sebagai apendisitis akut.

\section{SIMPULAN}

Telah dilaporkan kasus apendisitis akut supuratif pada seorang laki-laki berusia 52 tahun. Penyebab apendisitis akut pada kasus ini ialah obstruksi akibat infeksi Blastocystis hominis bentuk vakuol yang mengisi lumen apendiks, bahkan menginvasi dan merusak lapisan mukosa; hal ini tergolong sebagai penyebab yang jarang.

Diagnosis ditegakkan berdasarkan pemeriksaan histopatologik jaringan apendiks dengan pengecatan rutin hematoksilin eosin.

\section{DAFTAR PUSTAKA}

1. Fenoglia-Preiser CM, Noftsinger AE, Stemmermann GN, Lantz PE, Isaacson PG. Gastrointestinal Pathology. An atlas and text (Third Edition). Walters Kluwer, Philadelphia: Lippincott Williams \& Wilkins, 2008; p.834.

2. Sutanto I, Ismid IS, Sjarifuddin PK, Sungkar S. Buku Ajar Parasitologi Kedokteran (Edisi Keempat). Jakarta: Balai Penerbit FKUI, 2008; p.179-83.

3. Prasetyo RH. Diagnosis Blastocystis hominis pada tinja tikus. Majalah Kedokteran Nusantara. 2006;38(2): 174-5.

4. Chuong LS, Suresh K, Mak JW, Init I, Kathijah. Research Note. Prevalence of Blastocystis in animals from domesticated surroundings. The Southeast Asian Journal of Tropical Medicine and Public Health. 1996;27(4):850-2.

5. Lu CT, Sung YJ. Epidemiology of Blastocystis hominis and other intestinal parasites among the immigrant population in northeastern Taiwan by routine physical examination for residence approval. J Microbiol Immunol Infect. 2009;42:505-9.

6. Amin OM. The epidemiology of Blastocystis hominis in the United States. Research Journal of Parasitology. 2006;1(1):1-10. 
7. Senay H, MacPherson D. Blastocystis hominis: epidemiology and natural history. J. Infect Dis. 1990;162(4):98790.

8. Lamps LW. Infectious diseases of the GI tract. In: Odze RD, Goldblum JR, Crawford JW, editors. Surgical Pathology of the GI Tract, Liver, Biliary Tract, Pancreas (Vol 1). Philadelphia: Saunders Elsevier, 2004; p.51-2.

9. Yaowalark S. Is Blastocystis hominis a human pathogenic protozoan? J Trop Med parasitol. 2001;24:16-22.

10. Al-Kaissi E, Al-Magdi KJ. Pathogenicity of Blastocystis hominis in relation to enteropathogens in gastroenteritis cases in Baghdad. European Journal of Scientific Research. 2009;25(4):606-13.

11. Sheehan DJ, Raucher BG, McKitrick JC. Association of Blastocystis hominis with signs and symptoms of human disease. Journal of Clinical Microbiology. 1986;24(4):548-50.

12. Magdalena LJ. Blastocystis hominis salah satu penyebab diare. Ebers papyrus. 1996;2(1):27-32.
13. Tungtrongchitr A, Manatsathit S, Kositchaiwat C, Ongrotchanakun J, Munkong N, Chinabutr P, et al. Blastocystis Hominis infection in irritable bowel syndrome patients. Southeast Asian J Trop Med Public Health. 2004;35(3):705-10.

14. Dogruman-Al Funda, Kustimur S, Yoshikawa H, Tuncer C, Simsek Z, Tanyuksel M, et al. Blastocystis subtypes in irritable bowel syndrome and inflammatory bowel disease in Ankara, Turkey. Mem Inst Oswaldo Cruz, Rio de Janeiro. 2009;104(5):7247.

15. Stensvoid R, Brillowska-Dabrowska A, Vedel NH, Arendrup C. Detection of Blastocystis hominis in unpreserved stool specimens by using polymerase chain reaction. J. Parasitol. 2006; 90(25):1081-7.

16. Turner JR. The gastrointestinal tract. In: Kumar V, Abbas AK, Fausto N, Aster J $\mathrm{C}$, editors. Robbins and Cotran Pathologic Basis of Diseases (Eight Edition). Philadelphia: Saunders Elsevier, 2010; p.826-8. 